\title{
The Classification of Papaya using Digital Image Processing and Artificial Neural Networks
}

\author{
Feri Wibowo $^{1 *}$, Agus Harjoko², Hindayati Mustafidah ${ }^{2}$, Sriyanto $^{2}$ and Alvanita ${ }^{3}$ \\ ${ }^{1}$ Universitas Muhammadiyah Purwokerto, Indonesia \\ ${ }^{2}$ Universitas Gadjah Mada, Yogyakarta, Indonesia \\ ${ }^{3}$ Universitas Negeri Yogyakarta, Indonesia \\ *feriwibowo@ump.ac.id
}

\begin{abstract}
The quality identification process using a visual human eyes has its limitations, it requires more power to sort out. Furthermore, it has different levels of human perception in identifying the quality. This research develops digital image processing programs and artificial neural network for the quality classification of papaya Calina IPB-9 into three quality classes: Super, A, and B classes. Shape feature is extracted consistsing of compactness and roundness. Texture feature which is extracted consisting of the value of energy, entropy, contras, homogeneity, inverse difference moment, variance, and dissimilarity obtained by GLCM, another texture feature sought a feature LBP. Color feature is extracted consisting of the mean red, greeen, blue, hue, saturation, and value. These features serve as input to the training backpropagation neural network. The recognition process results shows the features of energy and entropy can distinguish quality classes of the papaya with the best accuracy rate that is equal to $87 \%$.
\end{abstract}

Keywords: Classification, Quality of Papaya, GLCM, Backpropagation

\section{Introduction}

Papaya is one of exported fruit commodities, some targetted countries for the export are are Hongkong, Singapore, Malaysia, Kuwait, Qatar, United Arab Emmirates, Bahrain, and Thailand. Based on the data issued by data center and agricultural information system of Agricultural Ministery of the Republic of Indonesia in 2014, number of Papaya export in the recent last three years since 2012, 2013, 2014 increases. The following increase in the last three years were $25.328 \mathrm{Kg}, 25.836 \mathrm{Kg}$, and $31.436 \mathrm{Kg}$. Based on the statistical data issued by Food \& Agriculture Organization (FAO) in 2000 to 2010 on the commodity production, Indonesia is one of the hugest Papaya producers in the world after Brazil, Mexico, India, and Nigeria [1].

The need of fresh papaya for export purposes requires quality controlling, so that it can compete with papaya producers from other countries. One of post-harvest problems is the process of papaya quality sorting. So far, the identification of sorting quality process is still implemented conventionally using visual human eyes having limitations. The process in this way has several disadvantages; it requires more human energy to sort out, the level of human perception in assessing the fruit quality is different, and the level of human consistency in the assessment does not guarantee the same standard because humans can experience fatigue [2].

Digital image processing technology and artificial neural network methods have been used in previous studies mainly related to other agricultural products. In a previous study, [3] it determined the level of maturity of tomatos (Lycopersicon esculentum Mill) using image processing methods and artificial neural network using means parameters. They are

Received (January 19, 2018), Review Result (May 20, 2018), Accepted (May 28, 2018) 
Red, Green, Blue means and a correlation as an input parameters on JTS. [4] In applying digital imaging and neural network processing technology to identify the physical quality of nutmeg (Myristica fragrans houtt) and physical test of the nutmeg seed, it was conducted in non-destructively way covering color, shape, and texture, and then its output was a quality grade of nutmeg seeds from ABC, Rimpel, and BWP qualities. Another previous research [5] used artificial neural networks and threshold rule for classifiying papaya maturity into three categories. They are immature, medium, and mature categories based on an average RGB values (red, green, blue). Another research [6] conducted design and construction of sorting machines with CCD camera sensors as image sensors and their processing units to perform citrus sorting. The result was the area of citrus land can be used as a reference for estimation of citrus fruit weight, it can also be used to determine citrus qualification according to the classes from class A to class $\mathrm{E}$.

This research develops digital image processing programs and artificial neural network for the quality classification of papaya Calina IPB-9 into three quality classes i.e., Super, $\mathrm{A}$, and B classes. The novelty of the proposed approach is that unlike previous researches, it uses digital image processing technology and artificial neural network method for classification of quality class of papaya (Carica Papaya L) Calina IPB-9 into three classes of quality. They are Super, A, and B classes. The classification was based on image parameter. They were feature values of form, texture, and the color obtaining its value from digital image processing. The value of the features obtained is then used as an input on algorithm learning of artificial neural network backpropagation [7-10].

\section{Proposed Method}

Stages of the process in the developed system included image acquisition process, image processing to obtain image features, and classification process with Backpropagation nerve network consisting of training and testing. The process of acquisition was conducted on papaya that has been picked and classified based on quality classes; they are Super, A, and B classes. This quality process was conducted by papaya farmers who are experts in assessing the quality of papaya, in addition to the process, the farmers are informed quality criteria of papaya based on the standard criteria issued by the National Standardization Agency (BSN) of Indonesia in 2009, with SNI number 4230: 2009. For consideration during the process, the image of papaya acquisition results will be processed using digital image processing technology; it was extracting image features, so it could obtain three types of features. Those were features of shape, texture, and color. Features of the form proposed were roundness and compactness features. The texture feature to look for were energy, entropy, contrast, homogeneity, inverse difference moment (idm), variance, dissimilarity and Local Binary Pattern (LBP) features. The proposed color feature was mean red, mean green, mean blue, mean hue, mean saturation, mean value. The features obtained from the digital image processing of the retrieval data of papaya image, which was stored in the database as a dataset. It would be used as input data at Backpropagation Neural Network training to obtain stage the weights, then after the weights obtained from the training, the weight would be stored into the database as a dataset at the testing stage to classify Calina IPB-9 papaya, based on its quality . Figure 1 shows the flow of papaya quality classification system.

\subsection{Image Acquisition}

Image acquisition process was conducted to Calina IPB-9 papaya that has been picked from its tree. The acquisition of the papaya which has been classified into quality classes, those were Super, A, and B classes. The taken image data were 192 with the details as follow: 156 training data consisting of 52 papaya image in super class, 52 papaya image in class $\mathrm{A}$, and 52 papaya image in B class, and the data testing were 36 data of papaya 
image. Samples of image acquisition results of Calina IPB-9 papaya were shown in Figure 1.

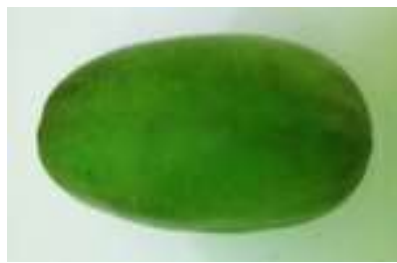

(a)

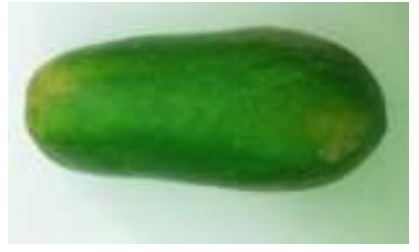

(b)

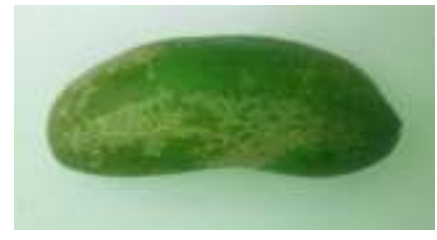

(c)

Figure 1. Pepaya Image of Calina IPB-9; (a) Super Class, (b) Class A, (c) Class B

\subsection{Preprosesing}

The prepocessing process was done in order to increase probability of success at a further processing stage in an image. The operations performed at the prepocessing stage included resizing and gray scaling operations. Resizing is the process of resolution changing or changing the horizontal and vertical sizes of the image. The resizing operation is to resize the image from the original size of $3264 \times 1836$ pixels to $1024 \times 575$ pixels in order to accelerate during digital image processing, because the larger image size, the more time required during the processing of digital images. Gray scaling is the process of converting images from RGB color images into gray scale images. On a gray scale image, the color is expressed with an intensity with its value is in between 0 and 255 , the 0 value is black and 255 means white. The conversion formula of image to gray scale or grayscaling can use equation (1).

$$
Y=0.2989 R+0.5870 G+0.1141 B
$$

\subsection{Segementation}

Image segmentation is a process intended to obtain the objects contained in the image or to divide the image into several areas with each object or region has similarity attributes. In an object containing only one object, it is distinguished from its background. Segmentation is also commonly done as an initial step for the process of classifying an object. The technique for the imagery segmenting is based on two basic properties of gray-level values: it is discontinuity and similarity between pixels. Image segmentation is based on a gray level discontinuity that can be said to be image separation based on abrupt change in the gray level [11]. Segmentation by selecting the threshold value automatically can be done by Otsu method. Otsu method is a method published by Nobuyuki Otsu in 1979. This method determines the threshold value by distinguishing two groups. They are object and background, which have a section that are stacked each other, based on the histogram.

\subsection{Feature Extraction}

The feature extraction process used grayscale imagery, binary imagery, and color imagery (RGB). Feature extraction was done to gain some features including shape, texture, and color features.

\subsubsection{Shape Feature}

The shape feature expressed through the area are compactness and roundness that are derived features of the perimeter and wide features. The shape feature is sourced from the binary image obtained from the segmentation process using the Otsu thresholding method. The value of compactness is a ratio between the perimeter and area, the value of 
cohesiveness ranges from 0 to 1 , the value 0 states that the object is a circle, the bigger compactness value, the object's shape is not more increasingly close to the form of a circle. The value of the roundness is the value of the comparison between the area of an object and the square of the perimeter, the value of the roundness feature is less than equal to 1 , the value 1 denotes that the object in a circle. The smaller roundness value, the less closer to the circle. The values of roundness and compactness uses equation (2) and equation (3).

$$
\begin{aligned}
& \text { roundness }=4 \pi \frac{A}{p^{2}} \\
& \text { compactness }=1-\frac{4 \pi A}{P^{2}}
\end{aligned}
$$

\subsubsection{Texture Feature}

Texture can be defined as a mutual relationship between the value of intensity of repeated neighboring pixels in a larger area than the distance of the relationship. The method used to obtain texture features can be divided into three groups namely statistical methods, structural methods, and spectral methods. According to [9] statistical methods use statistical calculations to form features. Examples included as statistical methods are GLCM (Gray Level Cooccurrence Matrices). Some texture features to look for based on GLCM are energy features, entropy, contrast, homogeneity, inverse difference moment (idm / local homogeneity), variance, and dissimilarity. The cooccurence matrix to search uses distance (1.0), which means one pixel to the right and zero pixels down, or the pixel pairs to be calculated is a distance of one pixel with an angle of $0^{0}$, as shown in Figure 2.

\begin{tabular}{|l|l|l|l|l|}
\hline 2 & 1 & 2 & 0 & 1 \\
\hline 0 & 2 & 1 & 1 & 2 \\
\hline 0 & 1 & 2 & 2 & 0 \\
\hline 1 & 2 & 2 & 0 & 1 \\
\hline 2 & 0 & 1 & 0 & 1 \\
\hline
\end{tabular}

(a)
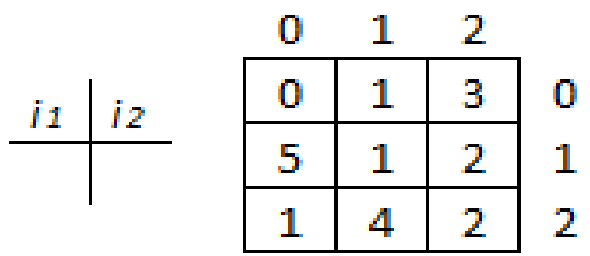

(b)

Figure 2. (a) $5 \times 5$ Sized Imagery of Three Intensities (0, 1, 2); (b) GLCM Distance (1.0)

After the matrix co occurrence, then look for the texture feature value that can be searched with equation (4) to equation (10).

$$
\begin{aligned}
& \text { energy }=\sum_{i=0}^{L-1} \sum_{j=0}^{L-1}[p(i, j)]^{2} \\
& \text { entropy }=-\sum_{i=0}^{L-1} \sum_{j=0}^{L-1} p(i, j) \log _{2}(p(i, j)) \\
& \text { kontras }=\sum_{i=0}^{L-1} \sum_{j=0}^{L-1}(i-j)^{2}(p(i, j)) \\
& \text { homogeneity }=\sum_{i=0}^{L-1} \sum_{j=0}^{L-1} \frac{P(i, j)}{1+|i-j|} \\
& \text { idm }=\sum_{i=0}^{L-1} \sum_{j=0}^{L-1} \frac{1}{1+(i-j)^{2}} p(i, j) \\
& \text { variance }=\sum_{i=0}^{L-1} \sum_{j=0}^{L-1}(i-\mu)^{2}(p(i, j)) \\
& \text { dissimilarity }=\sum_{i=0}^{L-1} \sum_{j=0}^{L-1}|i-j| p(i, j)
\end{aligned}
$$


In addition to texture features obtained from GLCM, other features to look for are local binary pattern feature (LBP), LBP is simply a binary code that describes local texture patterns. It is built with a boundary environment with gray value from its center [12]. The operator on LBP has a label marked with $\mathrm{P}$ and $\mathrm{R}$. P represents the number of neighboring pixels used in computation while $\mathrm{R}$ is the radius between the pixel of the center and the neighboring pixels. The LBP feature to search is based on the grayscale image to be performed using the $\mathrm{P}$ operation of 8 and $\mathrm{R}$ used is 1 . Then after determining $\mathrm{P}$ and $\mathrm{R}$, the next step is to compare the value of the intensity of the neighboring pixel with the center pixel intensity value, the neighboring pixel that has the value Intensity equal to or greater than the value of the intensity of the center point that is assigned a value of 1 otherwise it is given a value of 0 . After the neighboring pixels are given a value of 1 or 0 , the value of the neighboring pixels from 0 to 7 respectively multiplied by 2 to the power of 0 to 2 quadrate 7, then after it is summed up entirely to get the LBP value for the central pixel. The process of obtaining LBP values is shown in Figure 3.

\begin{tabular}{|l|l|l|}
\hline 6 & 5 & 2 \\
\hline 7 & 6 & 1 \\
\hline 9 & 8 & 7 \\
\hline
\end{tabular}

(a)

\begin{tabular}{|l|l|l|}
\hline$P_{0}$ & $P_{1}$ & $P_{2}$ \\
\hline$P_{7}$ & $P_{8}$ & $P_{3}$ \\
\hline$P_{6}$ & $P_{5}$ & $P_{4}$ \\
\hline
\end{tabular}

(b)

\begin{tabular}{|l|l|l|}
\hline 1 & 0 & 0 \\
\hline 1 & & 0 \\
\hline 1 & 1 & 1 \\
\hline
\end{tabular}

(c)

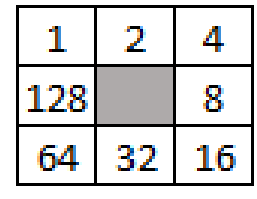

(d)

Figure 3. Process (a) The Original Image;

(b) The Central and Neighboring Pixel Position; (c) Thresholded; (c) Weights

\subsubsection{Color Feature}

Color features can be obtained through statistical calculations such as averages that can provide a size value of the distribution. The color features can be utilized for the purposes of identification of ornamental plants [13]. In this study, the researcher used images in RGB and HSV color space, so it is necessary to conduct a convertion from images in RGB color space to imagery in HSV space.

\subsection{Classification Design with Backpropagation Neural Network}

The backpropagation neural network training algorithm consists of two steps, namely forward propagation and backward propagation, steps of both forward and backward propagations are conducted on a network for each given pattern during the training network [14-17]. In a given network a pair of patterns comprising the desired input and output patterns, when a pattern is assigned to the network, so the weights are changed to minimize the difference in the network output and the desired output pattern [18-21]. The backpropagation network architecture to establish consists of 3 layers: the input layer, the hidden layer and the output layer [22]. The features obtained from the image of papaya will perform as input on the input layer on the backpropagation nerve network [23]. Features obtained from image processing are 16, then the input unit on the layer input will be 16 units, then in the hidden layer consists of 5 units. In the output layer there are 2 units, because there are 3 classes of papaya quality which will be classified, so there are 3 pairs of output pattern. They are class of Super $(1,1)$, class A $(1,0)$, and class B $(0,1)$. The backpropagation network architecture is shown in Figure 4. 


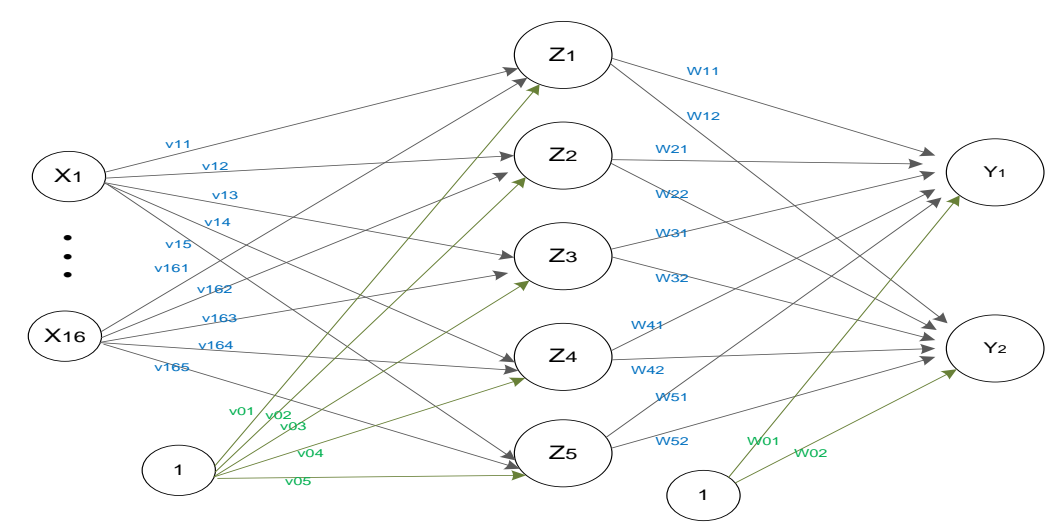

Figure 4. Established Artificial Neural Network Architecture

Testing will be done several times, starting from a combination of all features, features included as form features, features included as texture features, features included as color features, the best features resulted from the feature selection process. The accuracy of Calina IPB-9 papaya grade quality classification system is calculated by equation (11)

$$
\text { Accuracy }(\%)=\frac{\text { number recognized papaya image based on its class }}{\text { number of entire papaya image }} \times 100
$$

\section{Results and Analysis}

The feature extraction includes compactness and roundness features, then features energy, entropy, contrast, homogeneity, idm, variance, dissimilarity, and deviation standard of LBP histogram, features of mean red, mean green, mean blue, mean hue, mean saturation, and mean value. Table below 1 shows the average value of features of each grade of papaya image quality.

Table 1. Average Result of Extraction Result

\begin{tabular}{|l|c|c|c|}
\hline \multicolumn{1}{|c|}{ Feature } & SUPER & $\mathrm{A}$ & $\mathrm{B}$ \\
\hline Compactness & 0.580959929 & 0.574706845 & 0.673720570 \\
\hline Roundness & 0.4191849 & 0.428092536 & 0.317590949 \\
\hline Energy & 0.282673874 & 0.196039886 & 0.14863724 \\
\hline Entropy & 0.169006472 & 0.201432957 & 0.226100682 \\
\hline Contras & 0.127098174 & 0.13068448 & 0.154969185 \\
\hline Homogeneity & 0.937202291 & 0.936034182 & 0.925138505 \\
\hline Idm & 0.132501133 & 0.113911598 & 0.081385775 \\
\hline Variance & 0.1540195223 & 0.1337657977 & 0.1242928107 \\
\hline Dissimilarity & 0.125958447 & 0.128584198 & 0.150964249 \\
\hline St Dev LBP & 2.647012889 & 2.369366267 & 2.184981344 \\
\hline Mean $R$ & 0.259937077 & 0.281032791 & 0.324842233 \\
\hline Mean $G$ & 0.615352284 & 0.579956509 & 0.522944215 \\
\hline Mean B & 0.124710638 & 0.139010699 & 0.152213552 \\
\hline Mean H & 1.03270333 & 1.016020615 & 0.924183505 \\
\hline Mean $S$ & 0.805675091 & 0.768436842 & 0.721755843 \\
\hline Mean V & 0.629911971 & 0.596739469 & 0.540801223 \\
\hline
\end{tabular}


The features that have been obtained will be selected first before being used as input in the classification process. The selection of features is done by viewing the data distribution of the training image feature, each feature is taken maximum and minimum value in each class of quality. They are Super, A, and B classes. Maximum and minimum values obtained will be changed into graph to view difference of feature values between quality classes. Good features are going to view that each class will not overlap or at least a slight overlap in each class, and vice versa bad feature will overlap a lot in each class. Table 2 to Table 5 show data feature related to maximum values and minimal features of each quality class.

Table 2. Maximum and Minimum Features of Compactness and Roundness

\begin{tabular}{|l|c|c|c|c|}
\hline \multicolumn{2}{|c|}{ Feature } & SUPER & A & B \\
\hline \multirow{2}{*}{ Compactness } & Max & 0.838149539 & 0.778339563 & 0.92935781 \\
\cline { 2 - 5 } & Min & 0.475504099 & 0.464791254 & 0.442233412 \\
\hline \multirow{2}{*}{ Roundness } & Max & 0.524495901 & 0.535208746 & 0.490728388 \\
\cline { 2 - 5 } & Min & 0.161850461 & 0.221849672 & 0.07064219 \\
\hline
\end{tabular}

Table 3. Maximum Value and Minimal GLCM Texture Feature

\begin{tabular}{|l|l|c|c|c|}
\hline \multicolumn{2}{|c|}{ Feature } & SUPER & A & B \\
\hline \multirow{2}{*}{ Energy } & Max & 0.3538277 & 0.237287 & 0.177318 \\
\cline { 2 - 5 } Entropy & Min & 0.225767 & 0.154514 & 0.117413 \\
\hline \multirow{2}{*}{ Contrast Entropy } & Max & 0.1865785 & 0.2246725 & 0.2466505 \\
\cline { 2 - 5 } & Min & 0.1500783 & 0.182291 & 0.208605 \\
\cline { 2 - 5 } & Max & 0.161321 & 0.168363 & 0.23748 \\
\hline \multirow{3}{*}{ Homogeniety } & Max & 0.099646 & 0.10121 & 0.102197 \\
\cline { 2 - 5 } Idm & Min & 0.921414 & 0.921586 & 0.899289 \\
\hline \multirow{2}{*}{ Variance } & Max & 0.236734 & 0.2139 & 0.156796 \\
\cline { 2 - 5 } & Min & 0.065694 & 0.073419 & 0.044753 \\
\hline \multirow{2}{*}{ Dissimilarity } & Max & 0.2284057 & 0.2326744 & 0.2115706 \\
\cline { 2 - 5 } & Min & 0.065541 & 0.0454576 & 0.0449518 \\
\cline { 2 - 5 } & Max & 0.158183 & 0.159429 & 0.208064 \\
\hline
\end{tabular}

Table 4. Maximum and Minimum Values of Color Average Feature

\begin{tabular}{|l|l|r|r|r|}
\hline \multicolumn{2}{|c|}{ Feature } & \multicolumn{1}{c|}{ SUPER } & \multicolumn{1}{c|}{ A } & \multicolumn{1}{c|}{ B } \\
\hline \multirow{2}{*}{ Mean R } & Max & 0.34400957 & 0.357538 & 0.43219793 \\
\cline { 2 - 5 } & Min & 0.1911862 & 0.216057 & 0.25622858 \\
\hline \multirow{2}{*}{ Mean G } & Max & 0.66584239 & 0.637108 & 0.58842779 \\
\cline { 2 - 5 } & Min & 0.54205142 & 0.547356 & 0.45657939 \\
\hline \multirow{2}{*}{ Mean B } & Max & 0.1610035 & 0.193649 & 0.19326294 \\
\cline { 2 - 5 } & Min & 0.08211483 & 0.086487 & 0.08748374 \\
\hline \multirow{2}{*}{ Mean H } & Max & 1.14444578 & 1.1651039 & 1.092489287 \\
\cline { 2 - 5 } & Min & 0.875100121 & 0.8647892 & 0.666250532 \\
\hline \multirow{2}{*}{ Mean S } & Max & 0.86436702 & 0.857366 & 0.8343321 \\
\cline { 2 - 5 } & Min & 0.70996748 & 0.675286 & 0.63025329 \\
\hline \multirow{2}{*}{ Mean V } & Max & 0.68594041 & 0.655926 & 0.60912367 \\
\cline { 2 - 5 } & Min & 0.55156776 & 0.560773 & 0.4754543 \\
\hline
\end{tabular}


Table 5. Maximum and Minimal Values of LBP Stdev Histogram Feature

\begin{tabular}{|c|c|c|c|c|}
\hline \multicolumn{2}{|c|}{ Feature } & SUPER & A & B \\
\hline \multirow{2}{*}{ St Dev LBPH } & Max & 3186.70 & 3249.90 & 2897.83 \\
\cline { 2 - 5 } & Min & 1665.27 & 1397.31 & 1458.53 \\
\hline
\end{tabular}

From Table 5, the maximum and minimal values of features show almost all features overlap in each quality class of Calina IPB-9 papaya. However, when viewing the GLCM texture feature graph, it appears that the energy and entropy features overlap not too much, or it can beviewed the energy and entropy features overlap only in adjacent classes, no overlap between Super classes to class B or vice versa. Of the many features available, the most likely to be used as input in the next classification process is the energy and entropy features. Figure 5 shows the graph of maximum value and minimal GLCM features.

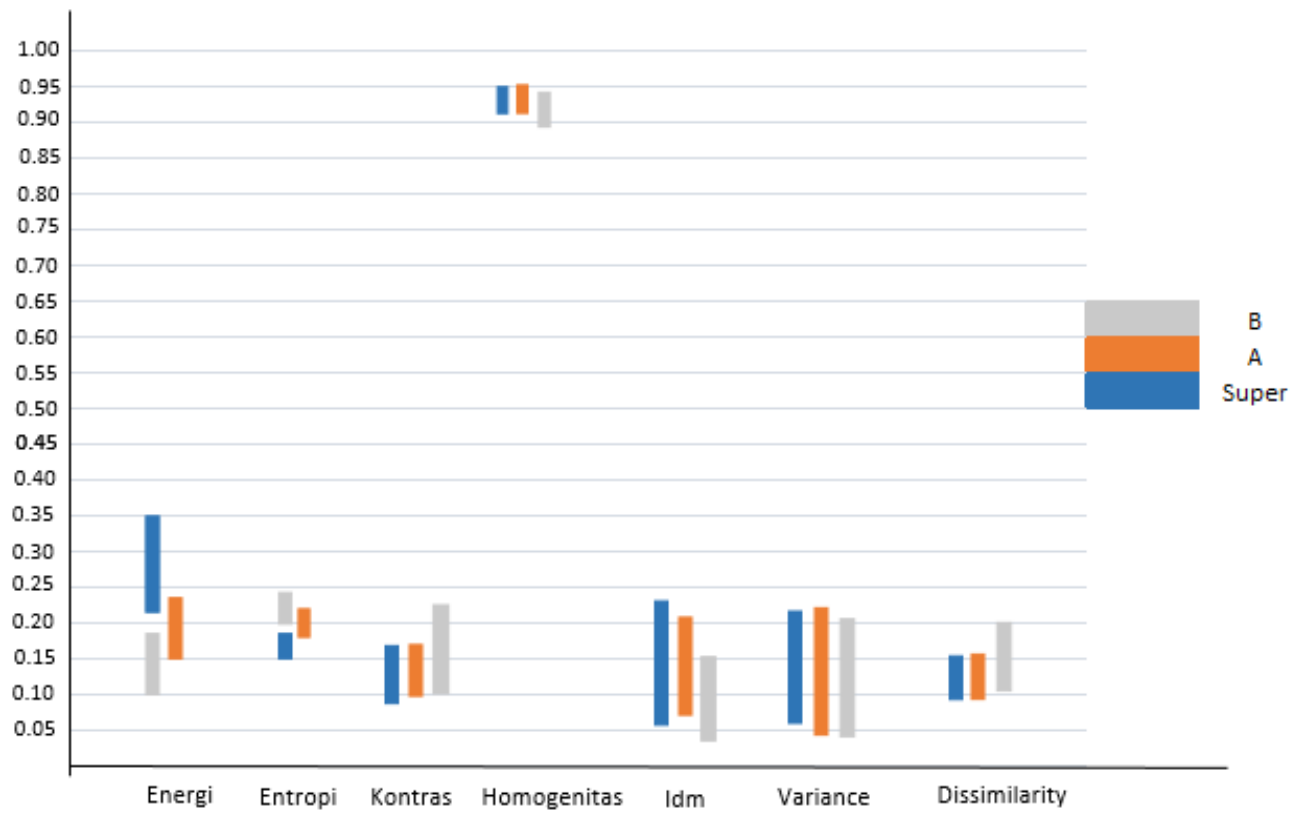

Figure 5. Graph of GLCM Texture Feature

The test of Calina IPB-9 Papaya quality classification system using backpropagation neural network is based on test data. Network training phase, using data train. They are 156 image data of Calina IPB-9 papaya. The network parameter is the value of learning rate of 0.02 , the epoch maximum value of 250,000 and the target error value of 0.001 . The test will be conducted several times starting from a combination of all features. They are features of form, texture, color, and the features that are the best features resulted from the feature selection process. The results of the classification recognation on the train data are presented in Table 6, and the classification results of the test data are shown in Table 7.

Table 6. Classification Results in Training Data

\begin{tabular}{|c|l|l|c|c|c|c|c|}
\hline No & \multicolumn{2}{|l|}{ The utilized features } & Super & A & B & $\begin{array}{c}\text { Total } \\
1\end{array}$ & $\begin{array}{c}\text { Recocn } \\
\text { ized } \\
(\%)\end{array}$ \\
\hline & $\begin{array}{l}\text { Compactness, Roundness, } \\
\text { Energi, Entropi, Kontras, } \\
\text { Homogenitas, Idm, Variance, } \\
\text { Dissimilarity, LBP St Dev, } \\
\text { Mean R, Mean G, Mean B, }\end{array}$ & $\begin{array}{l}\text { Recognized in } \\
\text { accordance to Target } \\
\text { Network }\end{array}$ & 52 & 0 & 0 & 52 & $33.33 \%$ \\
\hline
\end{tabular}




\begin{tabular}{|c|c|c|c|c|c|c|c|}
\hline & Mean H, MeanS, MeanV & $\begin{array}{l}\text { Not in accordance to } \\
\text { Target Network }\end{array}$ & 0 & 52 & 52 & 104 & \\
\hline \multirow[t]{2}{*}{2} & \multirow[t]{2}{*}{ Compactness, dan Roundness } & $\begin{array}{l}\text { Recognized in } \\
\text { accordance to Target } \\
\text { Network }\end{array}$ & 47 & 0 & 26 & 73 & \multirow[t]{2}{*}{$46.79 \%$} \\
\hline & & $\begin{array}{l}\text { Not in accordance to } \\
\text { Target Network }\end{array}$ & 5 & 52 & 26 & 83 & \\
\hline \multirow[t]{2}{*}{3} & \multirow{2}{*}{$\begin{array}{l}\text { Energi, Entropi, Kontras, } \\
\text { Homogenitas, Idm, Variance, } \\
\text { Dissimilarity }\end{array}$} & $\begin{array}{l}\text { Recognized in } \\
\text { accordance to Target } \\
\text { Network }\end{array}$ & 52 & 0 & 0 & 52 & \multirow[t]{2}{*}{$33.33 \%$} \\
\hline & & $\begin{array}{l}\text { Not in accordance to } \\
\text { Target Network }\end{array}$ & 0 & 52 & 52 & 104 & \\
\hline \multirow[t]{2}{*}{4} & \multirow[t]{2}{*}{ LBP St Dev } & $\begin{array}{l}\text { Recognized in } \\
\text { accordance to Target } \\
\text { Network }\end{array}$ & 52 & 0 & 0 & 52 & \multirow[t]{2}{*}{$33.33 \%$} \\
\hline & & $\begin{array}{l}\text { Not in accordance to } \\
\text { Target Network }\end{array}$ & 0 & 52 & 52 & 104 & \\
\hline \multirow[t]{2}{*}{5} & \multirow{2}{*}{$\begin{array}{l}\text { Mean R, Mean G, Mean B, } \\
\text { Mean H, Mean S, Mean V }\end{array}$} & $\begin{array}{l}\text { Recognized in } \\
\text { accordance to Target } \\
\text { Network }\end{array}$ & 52 & 0 & 0 & 52 & \multirow[t]{2}{*}{$33.33 \%$} \\
\hline & & $\begin{array}{l}\text { Not in accordance to } \\
\text { Target Network }\end{array}$ & 0 & 52 & 52 & 104 & \\
\hline \multirow[t]{2}{*}{6} & \multirow[t]{2}{*}{ Energy, dan Entropy } & $\begin{array}{l}\text { Recognized in } \\
\text { accordance to Target } \\
\text { Network }\end{array}$ & 52 & 48 & 51 & 151 & \multirow[t]{2}{*}{$96.79 \%$} \\
\hline & & $\begin{array}{l}\text { Not in accordance to } \\
\text { Target Network }\end{array}$ & 0 & 4 & 1 & 5 & \\
\hline
\end{tabular}

Table 6 above shows that number of recognized training images is not in accordance to the quality class based on the experiments of existing features. In the process of feature selection, it produces the best features. They are both energy and entropy. The combination of both features result 151 recognizable data according to the quality class and 5 identifiable data are not in accordance to the quality class or accuracy level of $96.79 \%$.

Table 7. Classification Test Results with Test Data

\begin{tabular}{|c|c|c|c|c|c|c|c|}
\hline No & \multicolumn{2}{|l|}{ Utilized Features } & Super & A & B & Total & $\begin{array}{c}\text { Recogniz } \\
\text { ed }(\%)\end{array}$ \\
\hline \multirow[t]{2}{*}{1} & \multirow{2}{*}{$\begin{array}{l}\text { Compactness, Roundness, } \\
\text { Energy, Entropi, Contrast, } \\
\text { Homogenitas, Idm, } \\
\text { Variance, Dissimilarity, } \\
\text { LBP St Dev, Mean R, Mean } \\
\text { G, Mean B, Mean H, Mean } \\
\text { S, Mean V }\end{array}$} & $\begin{array}{l}\text { Recognized in } \\
\text { accordance to } \\
\text { Target Network }\end{array}$ & 12 & 0 & 0 & 12 & \multirow[t]{2}{*}{$33.33 \%$} \\
\hline & & $\begin{array}{l}\text { Not in accordance } \\
\text { to Target Network }\end{array}$ & 0 & 12 & 12 & 24 & \\
\hline \multirow[t]{2}{*}{2} & \multirow{2}{*}{$\begin{array}{l}\text { Compactness, and } \\
\text { Roundness }\end{array}$} & $\begin{array}{l}\text { Recognized in } \\
\text { accordance to } \\
\text { Target Network }\end{array}$ & 7 & 0 & 8 & 15 & \multirow[t]{2}{*}{$46.79 \%$} \\
\hline & & $\begin{array}{l}\text { Not in accordance } \\
\text { to Target Network }\end{array}$ & 5 & 12 & 4 & 21 & \\
\hline \multirow[t]{2}{*}{3} & \multirow{2}{*}{$\begin{array}{l}\text { Energy, Entropy, Contrast, } \\
\text { Homogeniety, Idm, } \\
\text { Variance, Dissimilarity }\end{array}$} & $\begin{array}{l}\text { Recognized in } \\
\text { accordance to } \\
\text { Target Network }\end{array}$ & 12 & 0 & 0 & 12 & \multirow[t]{2}{*}{$33.33 \%$} \\
\hline & & $\begin{array}{l}\text { Not in accordance } \\
\text { to Target Network }\end{array}$ & 0 & 12 & 12 & 24 & \\
\hline \multirow[t]{2}{*}{4} & \multirow[t]{2}{*}{ LBP St Dev } & $\begin{array}{l}\text { Recognized in } \\
\text { accordance to } \\
\text { Target Network }\end{array}$ & 12 & 0 & 0 & 12 & \multirow[t]{2}{*}{$33.33 \%$} \\
\hline & & $\begin{array}{l}\text { Not in accordance } \\
\text { to Target Network }\end{array}$ & 0 & 12 & 12 & 24 & \\
\hline 5 & Mean R, Mean G, Mean B, & Recognized in & 12 & 0 & 0 & 12 & $33.33 \%$ \\
\hline
\end{tabular}




\begin{tabular}{|l|l|l|c|c|c|c|c|}
\hline & Mean H, MeanS, MeanV & $\begin{array}{l}\text { accordance to } \\
\text { Target Network }\end{array}$ & $\begin{array}{l}\text { Not in accordance } \\
\text { to Target Network }\end{array}$ & 0 & 12 & 12 & 24 \\
\hline 6 & Energy, and Entropy & $\begin{array}{l}\text { Recognized in } \\
\text { accordance to } \\
\text { Target Network }\end{array}$ & 11 & 10 & 10 & 31 & $86.11 \%$ \\
\cline { 3 - 8 } & $\begin{array}{l}\text { Not in accordance } \\
\text { to Target Network }\end{array}$ & 1 & 2 & 2 & 5 & \multirow{2}{*}{5} \\
\hline
\end{tabular}

From Table 7 above, it is known that the number of recognized test images based on the quality class and the number of recognized images does not match to the quality class based on the experimental combination of existing features. In the feature selection process, the best generated feature is energy and entropy, the combination of both two features resulting 31 recognizable data according to the quality class and 5 data are not in accordance to the quality class or accuracy of $86.11 \%$.

\section{Conclusion and Recommendation}

This research has developd digital image processing programs and artificial neural network for the quality classification of papaya. Based on the results of research on the quality classification of Calina IPB-9 Papaya with digital imaging technology and artificial neural network, it obtained the following conclusions: (1) The quality classification process of Calina Ipb-9 papaya is conducted using a program that has been successfully designed and created using digital image processing technology for feature extraction of papaya fruit and neural network with backpropagation training algorithm as its classification method; (2) The feature extraction process has several features: compactness and roundness feature, features of energy, entropy, contrast, homogeneity, idm, variance, dissimilarity, and standard deviation of LBP histogram, mean red, mean green, mean blue, mean hue, mean saturation, and mean value; (3) The result of the feature selection process gets the best feature of energy and entropy feature as both features experience the smallest overlap; (4) The process of classifying the training data using the energy and entropy features results the best accuracy of $96.79 \%$. As for the process of classification testing on the test data using energy and entropy features produce the best accuracy value of $86.11 \%$. Furthermore, it can be given suggestions for further research: (1) The classification process using other methods besides the backpropagation neural network, it is expected that the classification results are better; (2) Trying to extract other features either from features of form, texture, and color. It is expected to find out features with a high discriminatory level for each quality class.

\section{References}

[1] Economic and Social Development Department, Medium-term prospects for agricultural commodities (Tropical Fruits), http://www.fao.org/docrep/006/y5143e/y5143e1a.htm. FAO. (2010).

[2] E. Syaefullah, H. K. Purwadaria and Sutrisno, "Pengolahan Citra Digital dan Jaringan Saraf Tirua untuk Identifikasi Tingkat Ketuaan Pepaya", Prosiding Seminar Nasional Teknologi Inovatif Pascapanen Pertanian III, ISBN: 978-979-1116-32-9, Bogor, (2011).

[3] A. Hidayatullah, "Identifikasi Tingkat Kematangan Buah Tomat (Lycopersicon esculentum Mill) Menggunakan Metode pengolahan citra digital dan jaringan saraf tiruan”, Skripsi, Yogyakarta: UGM, (2013).

[4] L. Dinar, "Identifikasi Mutu Fisik Biji Pala (Myristica Fragrans Houtt) Dengan Teknologi Pengolahan Citra Digital Dan Jaringan Sarat Tiruan”, Tesis. Yogyakarta: UGM, (2012).

[5] H. Saad and A. Hussain, "Classification for the Ripeness of Papayas Using Artificial Neural Network (ANN) and Threshold Rule", Student Conference on Research and Development -SCOReD, 1-42440527-0/06, Selangor, (2006).

[6] U. Ahmad, R. Tjahjohutomo and Mardison, "Perancangan dan Konstruksi Mesin Sortasi dan Pemutuan Buah Jeruk dengan Sensor kamera CCD”, Junal Keteknikan Pertanian (jTEP), ISSN 0216-3365, Bogor, (2008). 
[7] N. M. Nawi, A. Khan, M. Z. Rehman, H. Chiroma and T. Herawan, "Weight optimization in recurrent neural networks with hybrid metaheuristic Cuckoo search techniques for data classification", Mathematical Problems in Engineering, (2015).

[8] H. Chiroma, A. Khan, A. I. Abubakar, Y. Saadi, M. F. Hamza, L. Shuib, A. Y. Gital and T. Herawan, "A new approach for forecasting OPEC petroleum consumption based on neural network train by using flower pollination algorithm”, Applied Soft Computing, vol. 48, (2016), pp. 50-58.

[9] S. Z. A. Bakar, R. Ghazali, L. H. Ismail, T. Herawan and A. Lasisi, "Implementation of Modified Cuckoo Search Algorithm on Functional Link Neural Network for Climate Change Prediction via Temperature and Ozone Data", In Recent Advances on Soft Computing and Data Mining, Springer, (2014), pp. 239-247.

[10] W. Waheeb, R. Ghazali and T. Herawan, "August. Time series forecasting using ridge polynomial neural network with error feedback", In International Conference on Soft Computing and Data Mining, Springer, (2016), pp. 189-200.

[11] A. Kadir and A. Susanto, "Teori dan Aplikasi Pengolahan Citra", Penerbit Andi, Yogyakarta, (2013).

[12] T. Ahonen, A. Hadid and M. Pietikainen, "Face Description with Local Binary Pattern: Aplication to Face Recognation", IEEE Transactions on pattern recognition, vol. 28, no. 12, (2004).

[13] A. Kadir, L. E. Nugroho, A. Susanto and P. I. Santosa, "Leaf Clasisification Using Shape, Color, and Texture Features", Internation Journal of Computer Trends and Technology, vol. 2, no. 1, (2011), pp. 225-230.

[14] A. Hermawan, "Jaringan Saraf Tiruan Teori dan Aplikasi”, Penerbit Andi, Yogyakarta, (2006).

[15] H. Chiroma, S. Abdulkareem and T. Herawan, "Evolutionary Neural Network model for West Texas Intermediate crude oil price prediction", Applied Energy, vol. 142, (2015), pp. 266-273.

[16] H. Chiroma, S. Abdul-Kareem, S. A. Muaz, A. Khan, E. N. Sari and T. Herawan, "Neural network intelligent learning algorithm for inter-related energy products applications", In International Conference in Swarm Intelligence, Springer, (2014) October, pp. 284-293.

[17] N. A. Husaini, R. Ghazali, L. H. Ismail and T. Herawan, "A Jordan pi-sigma neural network for temperature forecasting in batu pahat region", In Recent Advances on Soft Computing and Data Mining, Springer, (2014), pp. 11-24.

[18] N. M. Nawi, M. Z. Rehman, M. A. Aziz, T. Herawan and J. H. Abawajy, "Neural network training by hybrid accelerated cuckoo particle swarm optimization algorithm", In International Conference on Neural Information Processing, Springer, (2014) November, pp. 237-244.

[19] H. Chiroma, S. Abdul-Kareem, A. Khan, N. M. Nawi, A. Y. U. Gital, L. Shuib, A. I. Abubakar, M. Z. Rahman and T. Herawan, "Global warming: predicting OPEC carbon dioxide emissions from petroleum consumption using neural network and hybrid cuckoo search algorithm", PloS one, vol. 10, no. 8, (2015) pp. e0136140.

[20] R. Ghazali, Z. A. Bakar, Y. M. M. Hassim, T. Herawan and N. Wahid, "August. Functional link neural network with modified cuckoo search training algorithm for physical time series forecasting", In International Conference on Intelligent Computing, Springer, (2014), pp. 285-291.

[21] R. Ghazali, N. A. Husaini, L. H. Ismail, T. Herawan and Y. M. M. Hassim, "The performance of a Recurrent HONN for temperature time series prediction", In International Joint Conference on IEEE Neural Networks (IJCNN), (2014) July, pp. 518-524.

[22] N. M. Nawi, M. Z. Rehman, M. A. Aziz, T. Herawan and J. H. Abawajy, "An accelerated particle swarm optimization based Levenberg Marquardt back propagation algorithm", In International Conference on Neural Information Processing, Springer International Publishing, (2014) November, (pp. 245-253.

[23] F. Wibowo and A. Harjoko, "Klasifikasi Mutu Pepaya Berdasarkan Ciri Tekstur GLCM Menggunakan Jaringan Saraf Tiruan”, Khazanah Informatika: Jurnal Ilmu Komputer dan Informatika, vol. 3, no. 2, (2017) Desember, pp. 100-104. 
International Journal of Advanced Science and Technology

Vol.118 (2018) 